\title{
Hydrogeochemistry and isotope studies of groundwater in the Ga West Municipal Area, Ghana
}

\author{
David Saka $\cdot$ Tetteh T. Akiti $\cdot$ Shiloh Osae • \\ Michael K. Appenteng • Abass Gibrilla
}

Received: 14 May 2012/Accepted: 1 May 2013/Published online: 21 May 2013

(C) The Author(s) 2013. This article is published with open access at Springerlink.com

\begin{abstract}
This paper assesses groundwater in the $\mathrm{Ga}$ West Municipal Area of Ghana using hydrogeochemistry and isotope approaches. High salinity groundwaters are obtained in the municipality which poses problems for current and future domestic water supply exploitation. The increase in salinity is related to the dissolution of minerals in the host rocks and the evaporative concentration of solutes. The dominant groundwater composition in both shallow and deep wells sampled is $\mathrm{Na}-\mathrm{Cl}$. The concentration of the $\mathrm{Na}-\mathrm{Cl}$ was observed to increase substantially with well depths. The mixing of freshwater of the shallow hand dug wells with that of saline water of the deep boreholes was noted in the shift from $\mathrm{Ca}-\mathrm{HCO}_{3}$ facies to $\mathrm{Ca}-\mathrm{Cl}$ facies. Schoeller diagram showed that groundwater in the study area is recharged from a similar source. The Schoeller diagram also showed the gradual increase in concentration of the major ions with depth. This leads to salinization in the deep boreholes. The oxygen and hydrogen isotope compositions in the groundwater samples suggest that groundwater recharge is of meteoric origin with few samples showing evidence of evaporation. An average deuterium excess of rainfall of $14.2 \%$ was observed, which indicates the significance of kinetic
\end{abstract}

D. Saka $(\bowtie) \cdot$ M. K. Appenteng · A. Gibrilla

Nuclear Chemistry and Environmental Research Centre, GAEC, Box LG 80, Legon, Accra, Ghana

e-mail: davidsaka@live.com

T. T. Akiti

Graduate School of Nuclear and Allied Sciences, Box AE 1, Atomic Energy Kwabenya, Ghana

S. Osae

National Nuclear Research Institute, GAEC, Box LG 80, Legon, Accra, Ghana evaporation due to low humidity conditions prevalent in the study area. The d-excess also indicates modern recharge along the foothills of the Akwapim-Togo Ranges.

Keywords Deuterium excess - Major ions $\cdot$ Schoeller diagram $\cdot$ Salinity $\cdot$ Ghana

\section{Introduction}

The Ga West Municipal Area of Ghana is one of the fastest growing municipalities in the country. The fast growth rate is as a result of the areas closeness to the capital city, Accra, where there is a lot of inflow of migrant workers. The municipality has a population density of 491 persons per $\mathrm{km}^{2}$, which is much higher than the national average density of 79.3 persons per $\mathrm{km}^{2}$ (GSS 2002). However, the increase in population is not comparable with the provision of social amenities especially potable piped water supply. The result is that the communities now resort to groundwater as their main and sometimes the only source of water supply (GSS 2002).

The rural communities in the municipal area previously relied on raw surface waters for their water needs. These surface water sources included the Nsaki, Doblo, Ntafafa, Adaiso and Ponpon Rivers. However, with the increase in population, these sources have become inadequate especially during the dry seasons. Also, human activities such as sand winning and stone quarrying and other land use activities along the river banks in the area have left some of the surface water sources; in particular, the Nsaki River heavily polluted (Owusu and Gasu 2002), resulting in water-borne and water-related diseases (Kofie et al. 2008). Significant among the diseases is Buruli ulcer, which has a high prevalent rate in the municipal area. 
The provision of groundwater has therefore become an attractive source of suitable water supply. In Ghana, groundwater of sufficient quality is gradually becoming an integral part of the socioeconomic development. This resource forms the backbone of the rural water delivery system in the country and it is being tapped at various depths to meet growing needs. Groundwater use is the most cost effective means of rural water supply (Kortatsi 1994). This is because groundwater can be tapped at shallow depths in several areas of the country. Also, well yields are in many cases good (Gyau-Boakye and Dapaah-Siakwan 2000) and serve as adequate supply of water throughout the year. Lastly, when well sites are adequately protected, groundwater has excellent natural quality and requires minimal or no prior treatment.

Groundwater is increasingly being used for irrigation activities to supplement rain fed agriculture. In some cases, irrigation using groundwater from shallow wells forms the only source of livelihood of some rural communities due to the recent unpredictable patterns of rainfall in the country. It has been noted that achieving the Millennium Development Goals (MDGs) of the government of Ghana is intricately linked to the sustainable development and utilization of available groundwater and surface water resources to meet growing development needs (Yidana et al. 2011). It therefore goes without saying that sustainable management of groundwater forms the yardstick to the future of the agricultural sector which is the main engine of development in Ghana.

However, groundwater resources in the $\mathrm{Ga}$ West Municipal Area is under threat from increased abstraction as a result of the population explosion, the rapid increase in the number of wells and the progress in pumping technology. Another major threat is from the pollution due to inappropriate disposal of domestic waste. Quite often due to the poor management of hand dug wells in particular, polluted surface waters seep into them with its attendant water-borne diseases (Nkansah et al. 2010).

To ensure the sustainable development and management of groundwater, there is a need to study the details of the various aquifer systems to understand the hydrogeochemistry of the aquifers as well as the associated human effects on the groundwater resource. The informed evaluation and management of groundwater begins with the identification of the major recharge areas.

In this work, hydrochemical data is used to study the influence of geology on the groundwater and to determine the chemical quality of the waters in the municipality. The study also aims to provide insight into the specific locations of groundwater recharge using the stable isotopes of hydrogen and oxygen, and finally study the relationship between the shallow and the deep wells in the area.

\section{Location and climate}

The study area lies between latitude $5^{\circ} 48^{\prime} \mathrm{N}$ to $5^{\circ} 29^{\prime} \mathrm{N}$ and longitude $0^{\circ} 8^{\prime} \mathrm{W}$ to $0^{\circ} 30^{\prime} \mathrm{W}$. It occupies a land area of approximately $710.2 \mathrm{~km}^{2}$ with about 1,028 communities (GSS 2002). Some major communities include Amasaman, Sarpeiman and Pokuase.

The study area lies in the savannah zone and features a tropical savannah climate. The average annual rainfall is about $730 \mathrm{~mm}$, which falls primarily during two rainy seasons. The first rainy season begins in mid-April and ends in June. The second season begins in mid-August and ends in November as depicted in Fig. 1.

There is little variation in temperature throughout the year. On the basis of recent meteorological data obtained from the Ghana Meteorological Agency, the mean monthly temperature ranges from $29.4{ }^{\circ} \mathrm{C}$ in August (the coolest) to $34.8{ }^{\circ} \mathrm{C}$ in March (the hottest). The cooler months tend to be more humid than the warmer months. Monthly temperature and amount of rainfall distribution and relative humidity for the study area are shown in Figs. 1 and 2, respectively.

\section{Geology and hydrogeology}

The study area is underlain by the Cape Coast Granite Complex and rocks of the Togo Formation. The Cape Coast Granite Complex consists of a heterogeneous group of rocks which occupies about $80-90 \%$ of the study area. The bulk of the Cape Coast Granite Complex is a granitic to quartz-dioritic gneiss which in the field is seen to change gradationally from fine to medium grained foliated biotitequartz-diorite gneiss to exclusively hornblende-quartzdiorite gneiss (Ahmed et al. 1977).

Amphibolites, hornblendes and basic hornblende gneisses occur as inclusions or xenoliths within the host gneisses and granites. These gneissic rocks are intruded by both acidic and basic igneous rocks which include white

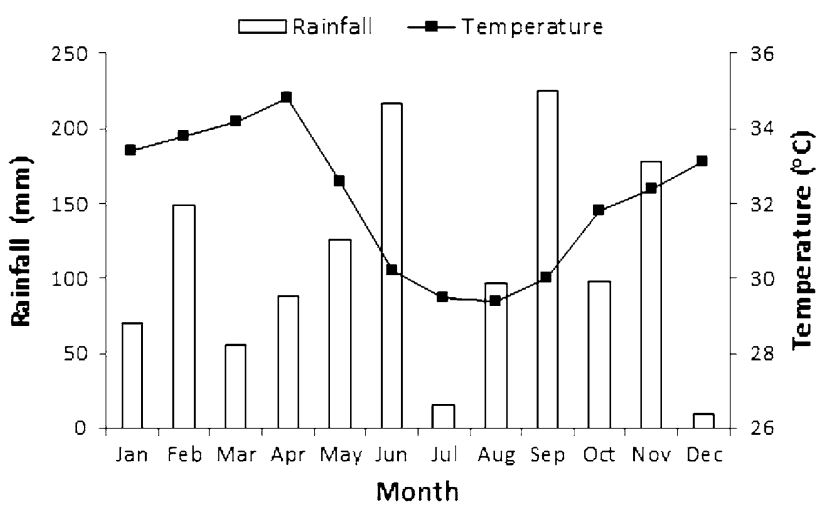

Fig. 1 Temperature and amount of rainfall distribution in the Ga West Municipal Area 


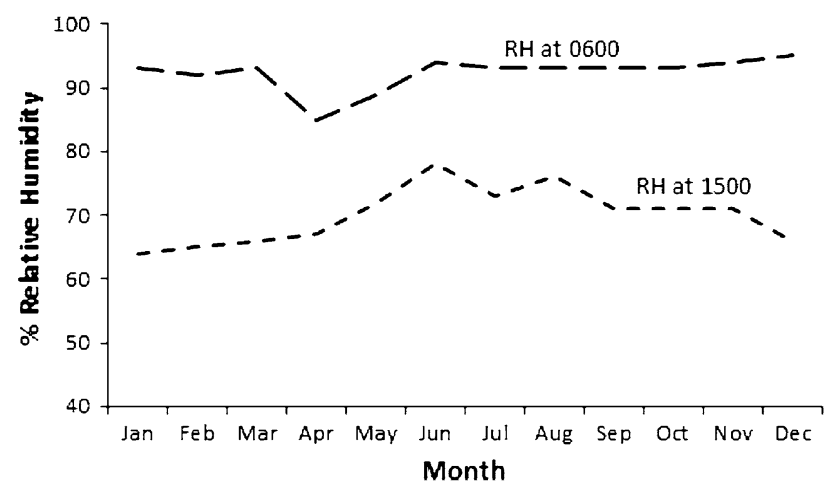

Fig. 2 Monthly (\%) relative humidity at the Ga West Municipal Area

and pink pegmatite, aplites, granodiorite and dykes. The dykes, which are mostly dolerite, are probably the youngest units recognised in the area, and are less numerous than the acidic intrusives.

The groundwaters in the Cape Coast Granite Complex usually occur in the weathered zone. Borehole depths vary from 9.0 to $103.0 \mathrm{~m}$ and the static water level ranges from 1.5 to $8.2 \mathrm{~m}$ with a mean value of $4.2 \mathrm{~m}$ (WRRI 2003). Available records show that borehole yield ranges from 0.72 to $9 \mathrm{~m}^{3} \mathrm{~h}^{-1}$. Average yield is $3.06 \mathrm{~m}^{3} \mathrm{~h}^{-1}$ (Ganyaglo et al. 2010).

The Togo formation has quartzites as the main rock types, followed by phyllites and schists. These rock types unconformably overlie Dahomeyan gneisses. The bulk of these rocks are found in Katapor, in the north eastern part of the study area where mainly cataclastic quartzites interbedded with phyllites are present (Saunders 1969). The rocks consist of arenaceous, pebbly sediments which have been indurated, folded and faulted with high grades of metamorphism in places. The rocks themselves are impervious but contain opening along joint, bedding and cleavage planes. Where these openings are extensive, good supplies of groundwater are developed from boreholes. Where quartzites are in contact with argillaceous rocks of the valleys, springs are usually found such as the springs that occur in the Akwapim Range (Kesse 1985).

The depth of boreholes within the Togo formation varies from 28.0 to $97.0 \mathrm{~m}$. The mean thickness of the weathered zone ranges from 3.0 to $36.0 \mathrm{~m}$. The static water level ranges between 1.1 and $17.9 \mathrm{~m}$. Borehole yields are highly variable and range between 0.6 and $6.0 \mathrm{~m}^{3} \mathrm{~h}^{-1}$ with a mean value of $2.8 \mathrm{~m}^{3} \mathrm{~h}^{-1}$.

\section{Sampling and analysis}

Forty one water points were sampled during January and February of 2010, including 10 boreholes, 17 hand dug wells, 11 rainfall events and 3 surface water samples. The location of boreholes, hand dug wells and surface water sampling points are shown in Fig. 3. Surface water samples were taken at different locations along the path of the Nsaki River. Groundwater samples were obtained from active water supply wells used for domestic purposes. The samples were taken after removing several well volumes of water using pumps installed in these wells. This was done to purge the aquifer of stagnant water and to acquire fresh aquifer samples for analysis.

All the water samples were collected in $250 \mathrm{~mL}$ pre-conditioned high density polyethylene bottles. The bottles were conditioned by washing with $5 \%$ nitric acid, and then rinsed several times with distilled water. This was carried out to ensure that the sampling bottles were free from contaminants.

Temperature, electrical conductivity (EC) and total dissolved solids (TDS) measurements were conducted in situ in the field by the $\mathrm{HACH}$ conductivity and $\mathrm{pH}$ metre. On-site testing of these variables was necessary since these parameters are likely to change during transport. $\mathrm{HCO}_{3}{ }^{-}$titration was done at the wellhead using a HACH digital Titrator. Sodium $\left(\mathrm{Na}^{+}\right)$and potassium $\left(\mathrm{K}^{+}\right)$ were analysed using flame emission photometer (Sherwood model 420), magnesium $\left(\mathrm{Mg}^{2+}\right)$ and calcium $\left(\mathrm{Ca}^{2+}\right)$ using Varian AA240 Fast Sequential Atomic Absorption Spectrometer. Chloride $\left(\mathrm{Cl}^{-}\right)$, sulphate $\left(\mathrm{SO}_{4}{ }^{2-}\right)$ and nitrate $\left(\mathrm{NO}_{3}{ }^{-}\right)$were analysed using ICS-90 ion chromatography at the Nuclear Chemistry and Environmental Research Centre, Ghana Atomic Energy Commission.

All samples were analysed for oxygen-18 and deuterium in the Isotope Hydrology Laboratory of the Nuclear Chemistry and Environmental Research Centre, Ghana Atomic Energy Commission. The samples were analysed using the off-axis integrated cavity output spectroscopy (OA-ICOS) Los Gatos Research DT-100 Liquid-Water Isotope Analyser (Model 908-008-2000). All stable isotope data are reported in the usual $\delta$ notation, where

$\delta=\left[\frac{R_{\text {sample }}}{R_{\text {vsmow }}}-1\right] \times 1000$

$R$ represents either the ${ }^{18} \mathrm{O} /{ }^{16} \mathrm{O}$ or $\mathrm{D} / \mathrm{H}$ ratio of the sample, and $R_{\mathrm{vsmow}}$ is the isotope ratio of the V-SMOW, a reference standard.

\section{Results and discussions}

Physical properties

The statistical summaries of the parameters analysed are presented using the Box and Whisker plots in Fig. 4, while Table 1 presents the data for the major hydrochemical parameters analysed for this study. The $\mathrm{pH}$ of groundwaters 


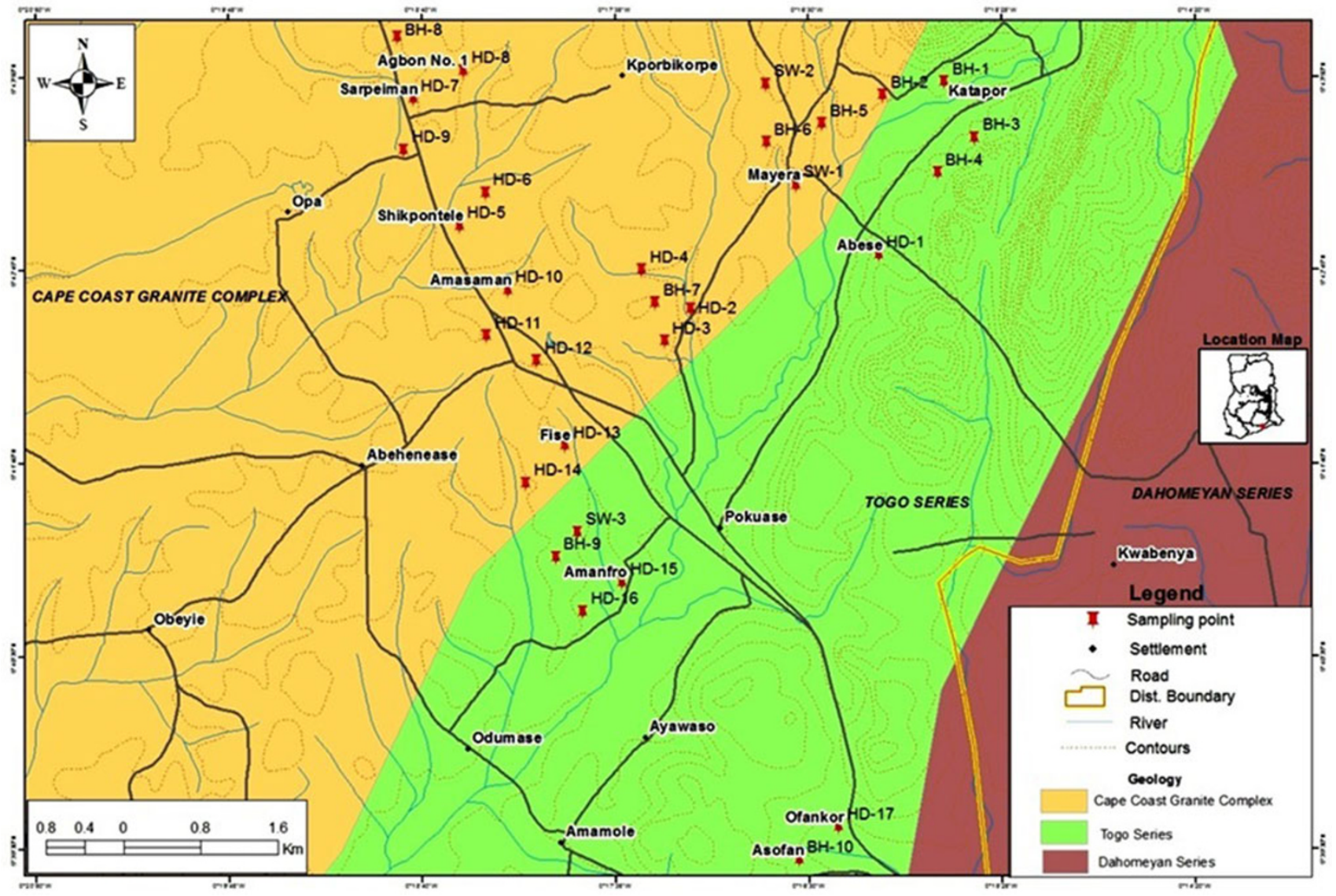

Fig. 3 Geology map and sampling sites of study area

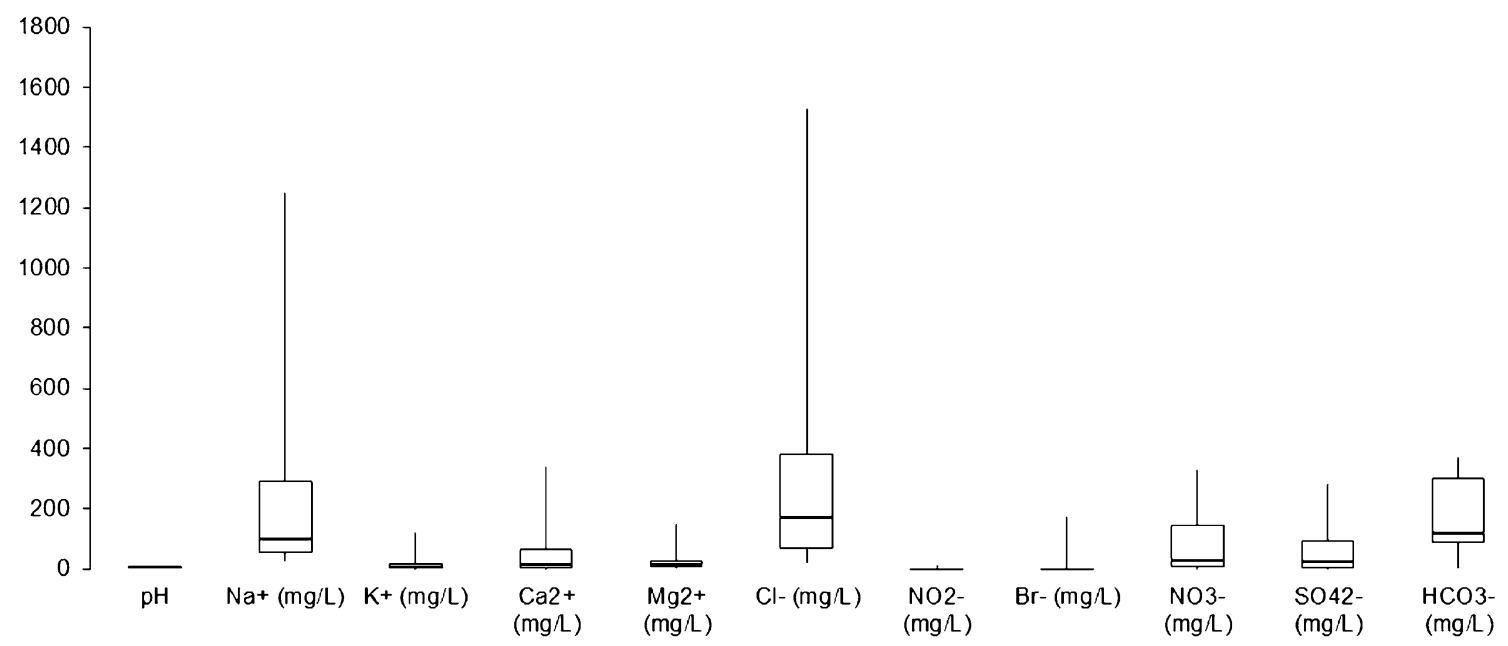

Fig. 4 Box plots for the chemical parameters

in the study area is slightly acidic to neutral (4.27-7.64). The lowest $\mathrm{pH}$ occurred at Asofaa while the highest $\mathrm{pH}$ was recorded at Agbon No. 1. The waters in the granites have $\mathrm{pH}$ values ranging from 5.7 to 7.64 . Similar results were obtained by Fianko et al. (2010) and Ganyaglo et al.
(2010) in the Cape Coast Granitoids of the Densu River Basin. The neutral to slightly acidic waters in the granitoids may be due to the dissolution of silicates and carbonates (Pelig-Ba 1989). The acidic waters (4.27-5.94) were observed in the Katapor and Asofaa areas within the 
Table 1 Chemical composition (meq/L) of groundwater and surface water samples from the Ga West Municipal Area

\begin{tabular}{|c|c|c|c|c|c|c|c|c|c|c|c|c|c|c|c|}
\hline $\begin{array}{l}\text { Sample } \\
\text { no. }\end{array}$ & $\begin{array}{l}\text { Sample } \\
\text { location }\end{array}$ & $\begin{array}{l}\text { Well } \\
\text { ID }\end{array}$ & $\begin{array}{l}\text { Well depth } \\
\text { (m) }\end{array}$ & $\mathrm{pH}$ & $\begin{array}{l}\text { Temp } \\
\left({ }^{\circ} \mathrm{C}\right)\end{array}$ & $\begin{array}{l}\text { EC } \\
(\mu \mathrm{S} / \mathrm{cm})\end{array}$ & $\begin{array}{l}\text { TDS } \\
(\mathrm{mg} / \mathrm{L})\end{array}$ & $\mathrm{Na}^{+}$ & $\mathrm{K}^{+}$ & $\mathrm{Ca}^{2+}$ & $\mathrm{Mg}^{2+}$ & $\mathrm{Cl}^{-}$ & $\mathrm{NO}_{3}^{-}$ & $\mathrm{SO}_{4}{ }^{2-}$ & $\mathrm{HCO}_{3}{ }^{-}$ \\
\hline 1 & Katapor & BH-1 & 76.8 & 5.27 & 28.9 & 556 & 251 & 2.30 & 0.15 & 1.08 & 1.12 & 1.94 & 0.53 & 0.17 & 1.64 \\
\hline 2 & Katapor & BH-2 & 94.1 & 5.36 & 29 & 1091 & 493 & 7.65 & 0.09 & 0.20 & 1.44 & 4.91 & 0.31 & 0.01 & 1.80 \\
\hline 3 & Katapor & BH-3 & 72.7 & 4.58 & 31.5 & 350 & 148.1 & 1.95 & 0.22 & 1.04 & 1.09 & 1.30 & 0.26 & 0.46 & 0.25 \\
\hline 4 & Katapor & $\mathrm{BH}-4$ & 97.4 & 5.94 & 28.7 & 4540 & 2200 & 22.74 & 0.17 & 16.87 & 6.05 & 30.98 & 2.31 & 3.51 & 4.84 \\
\hline 5 & Mayera & SW-1 & - & 6.49 & 27.8 & 124.1 & 55.9 & 1.44 & 0.10 & 0.05 & 2.31 & 0.86 & 0.08 & 0.09 & 0.90 \\
\hline 6 & Mayera & $\mathrm{BH}-5$ & 83 & 6.39 & 27.7 & 6000 & 3000 & 4.43 & 0.22 & 6.38 & 6.56 & 38.03 & 0.01 & 4.07 & 7.29 \\
\hline 7 & Mayera & BH-6 & 73 & 6.56 & 28.1 & 2990 & 1434 & 23.74 & 0.78 & 2.93 & 2.24 & 10.46 & 3.61 & 2.07 & 5.82 \\
\hline 8 & Mayera & SW-2 & - & 7.54 & 28.6 & 659 & 298 & 3.07 & 0.10 & 0.84 & 0.96 & 2.96 & 0.10 & 0.01 & 3.44 \\
\hline 9 & Abese & HD-1 & 21 & 4.74 & 27.7 & 1151 & 536 & 11.57 & 0.05 & 0.05 & 0.35 & 15.22 & 0.24 & 0.89 & 1.48 \\
\hline 10 & Afiaman & HD-2 & 24 & 6.89 & 28.9 & 2190 & 1023 & 24.22 & 0.33 & 1.02 & 0.67 & 10.16 & 2.68 & 2.68 & 4.92 \\
\hline 11 & Afiaman & HD-3 & 27 & 6.85 & 28.2 & 3120 & 1500 & 20.17 & 0.43 & 5.94 & 2.33 & 11.54 & 4.76 & 2.58 & 9.34 \\
\hline 12 & Afiaman & BH-7 & 83 & 6.26 & 29.5 & 3770 & 1779 & 22.78 & 0.48 & 14.36 & 4.34 & 17.37 & 0.74 & 1.97 & 5.65 \\
\hline 13 & Afiaman & HD-4 & 18.7 & 6.4 & 28.7 & 808 & 367 & 4.62 & 0.39 & 0.76 & 1.36 & 2.43 & 1.00 & 0.68 & 4.02 \\
\hline 14 & Shikpontele & HD-5 & 20.1 & 7.05 & 28.8 & 491 & 271 & 2.89 & 0.13 & 0.32 & 1.75 & 2.00 & 0.67 & 0.30 & 1.48 \\
\hline 15 & Shikpontele & HD-6 & 18.2 & 6.12 & 28.4 & 443 & 200 & 2.21 & 0.05 & 0.27 & 2.02 & 0.71 & 0.27 & 0.29 & 1.88 \\
\hline 16 & Sarpeiman & HD-7 & 25.3 & 6.43 & 28.9 & 3160 & 1495 & 15.74 & 0.10 & 9.45 & 1.78 & 12.20 & 1.44 & 1.40 & 7.13 \\
\hline 17 & Agbon no. 1 & HD-8 & 17 & 7.64 & 27.9 & 989 & 457 & 5.30 & 0.56 & 0.98 & 0.98 & 7.11 & 2.35 & 0.49 & 2.05 \\
\hline 18 & Agbon no. 1 & BH-8 & 81 & 6.26 & 30.3 & 1231 & 549 & 5.34 & 0.22 & 0.61 & 1.38 & 4.91 & 0.12 & 0.01 & 4.92 \\
\hline 19 & Sarpeiman & HD-9 & 26 & 6.49 & 29 & 1205 & 550 & 4.35 & 0.75 & 6.72 & 2.57 & 3.61 & 2.91 & 0.59 & 1.72 \\
\hline 20 & Amasaman & HD-10 & 17 & 7.1 & 29 & 505 & 224 & 2.40 & 0.03 & 0.50 & 0.72 & 1.24 & 0.48 & 0.67 & 1.88 \\
\hline 21 & Amasaman & HD-11 & 24 & 6.46 & 30.7 & 1659 & 738 & 9.78 & 0.22 & 3.89 & 5.76 & 7.32 & 2.38 & 1.37 & 3.03 \\
\hline 22 & Amasaman & HD-12 & 16.9 & 5.94 & 30.1 & 405 & 176 & 1.13 & 0.65 & 0.23 & 0.56 & 2.58 & 0.32 & 0.01 & 1.48 \\
\hline 23 & Fise & HD-13 & 18 & 6.54 & 28.3 & 575 & 260 & 3.06 & 0.25 & 0.42 & 0.66 & 5.21 & 0.28 & 0.00 & 2.46 \\
\hline 24 & Fise & HD-14 & 21 & 5.7 & 30.1 & 736 & 325 & 4.43 & 0.25 & 1.19 & 1.78 & 6.54 & 0.01 & 1.74 & 0.57 \\
\hline 25 & Amanfro & HD-15 & 19.7 & 6.03 & 28.7 & 850 & 454 & 5.17 & 0.13 & 1.13 & 2.52 & 4.56 & 0.01 & 5.37 & 1.88 \\
\hline 26 & Amanfro & ВH-9 & 78.6 & 7.56 & 31 & 8450 & 4020 & 54.30 & 0.45 & 0.14 & 12.43 & 43.14 & 0.12 & 5.87 & 11.72 \\
\hline 27 & Amanfro & HD-16 & 19.3 & 6.16 & 28.5 & 361 & 162.1 & 2.17 & 0.04 & 0.12 & 0.35 & 0.76 & 0.01 & 0.52 & 1.15 \\
\hline 28 & Amanfro & SW-3 & - & 6.59 & 28.7 & 315 & 140.8 & 1.92 & 0.12 & 0.20 & 0.23 & 0.63 & 0.08 & 0.18 & 1.48 \\
\hline 29 & Asofaa & BH-10 & 64.7 & 4.27 & 29.4 & 1011 & 453 & 8.04 & 0.78 & 0.35 & 0.59 & 5.19 & 1.59 & 0.11 & 0.08 \\
\hline 30 & Ofankor & HD-17 & 23.1 & 5.83 & 29.1 & 1071 & 484 & 4.14 & 0.13 & 2.79 & 1.31 & 3.88 & 0.55 & 0.01 & 3.85 \\
\hline
\end{tabular}

Table 2 Spearman rank correlation coefficients of major ions concentration in groundwater of the Ga West Municipal Area

\begin{tabular}{|c|c|c|c|c|c|c|c|c|}
\hline & $\mathrm{Na}^{+}$ & $\mathrm{K}^{+}$ & $\mathrm{Ca}^{2+}$ & $\mathrm{Mg}^{2+}$ & $\mathrm{Cl}^{-}$ & $\mathrm{HCO}_{3}{ }^{-}$ & $\mathrm{SO}_{4}^{2-}$ & TDS \\
\hline $\mathrm{K}^{+}$ & -0.12 & & & & & & & \\
\hline $\mathrm{Ca}^{2+}$ & 0.28 & 0.26 & & & & & & \\
\hline $\mathrm{Mg}^{2+}$ & 0.66 & 0.18 & 0.33 & & & & & \\
\hline $\mathrm{Cl}^{-}$ & 0.72 & -0.23 & 0.41 & 0.70 & & & & \\
\hline $\mathrm{HCO}_{3}{ }^{-}$ & 0.58 & 0.47 & 0.40 & 0.69 & 0.42 & & & \\
\hline $\mathrm{SO}_{4}{ }^{2-}$ & 0.65 & -0.14 & 0.31 & 0.70 & 0.71 & 0.48 & & \\
\hline TDS & 0.82 & -0.07 & 0.45 & 0.69 & 0.94 & 0.63 & 0.69 & \\
\hline $\mathrm{NO}_{3}^{-}$ & 0.08 & 0.27 & 0.33 & 0.13 & -0.02 & 0.41 & 0.33 & 0.15 \\
\hline
\end{tabular}

Bold values indicate parameters with high positive correlation $r=0.3$ significant at $1 \%$ level 
Togo Formation. The formation has rock types such as phyllites and schists which can produce acidic waters (Wright et al. 1985).

The groundwater temperatures range between $27.7^{\circ} \mathrm{C}$ in the Togo Formation and $31.5^{\circ} \mathrm{C}$ in the Cape Coast Granitoids, with a mean value of $29.0{ }^{\circ} \mathrm{C}$. Lower temperatures occur at higher topographic elevations, in areas close to the foothills of the Akwapim-Togo Ranges. These areas have forest cover which may account for the lower

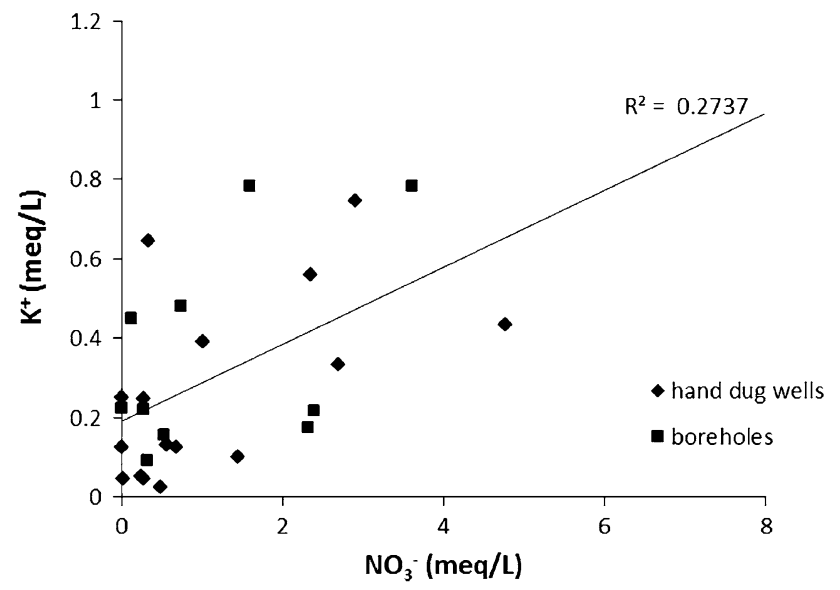

Fig. 5 Correlation plot between $\mathrm{K}$ and $\mathrm{NO}_{3}$ for groundwater samples from the Ga West Municipal Area temperatures. The higher temperatures were recorded at HD-15, HD-11 and BH-10 (Fig. 3) within the southern parts of the study area.

The EC values range from $350 \mu \mathrm{S} / \mathrm{cm}$ in the hand dug wells to $8,450 \mu \mathrm{S} / \mathrm{cm}$ in the boreholes. A mean of 2,077 $\mu \mathrm{S} / \mathrm{cm}$ was recorded. This high salinity and total hardness are found to be the most critical water quality parameters exceeding the permissible limits of drinking water standards. The boreholes have greater depths and may have dissolved more aquifer materials leading to the high salinity. Quite a number of these boreholes have been abandoned due to the water hardness; the communities rather resort to the shallow hand dug wells for their water needs. The TDS distribution of the groundwaters follows the same trend as that of the EC (148.1-4020 mg/L). The trend of increasing TDS is also similar to that of increasing concentrations of major cations and anions except $\mathrm{HCO}_{3}{ }^{-}$.

\section{Major ion chemistry}

The major cation concentrations were generally high with $\mathrm{Na}^{+}$being the most dominant cation. The relative abundance of the ions is in the order $\mathrm{Na}^{+}>\mathrm{Ca}^{2+}>$ $\mathrm{Mg}^{2+}>\mathrm{K}^{+}$. Also, $\mathrm{Cl}^{-}$is the most dominant anion followed by $\mathrm{HCO}_{3}{ }^{-}, \mathrm{SO}_{4}{ }^{2-}$ and $\mathrm{NO}_{3}{ }^{-}$in that order. $\mathrm{Na}^{+}$and
Fig. 6 Classification of hydrochemical facies using the piper plot
Piper Plot

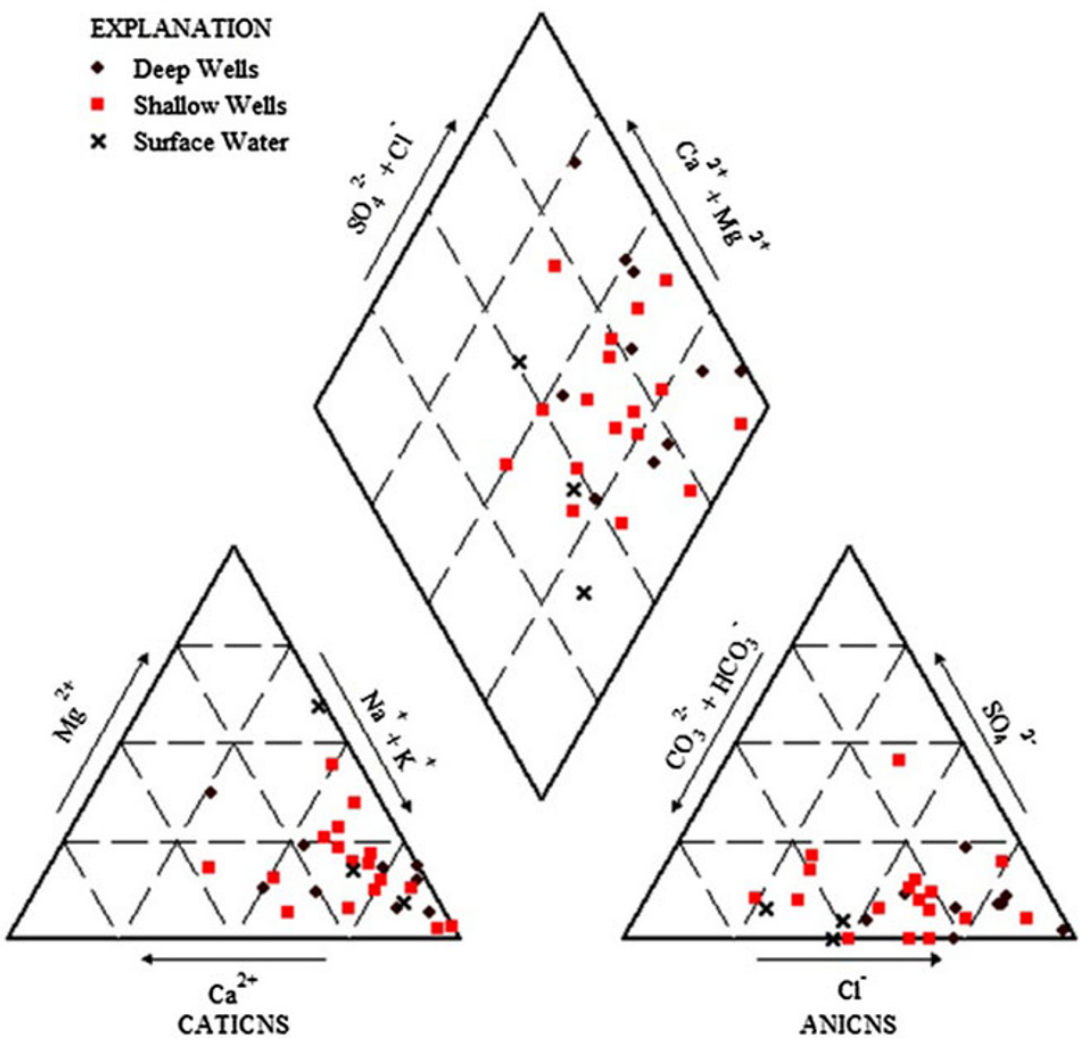




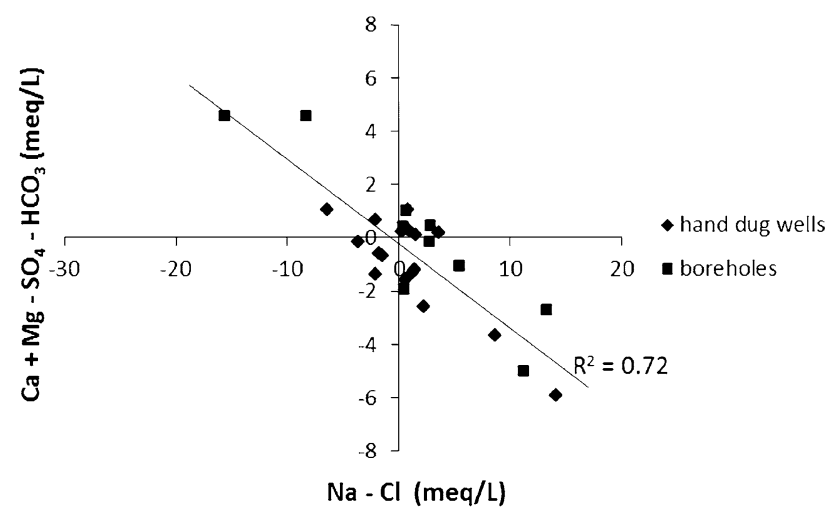

Fig. $7 \mathrm{Na}-\mathrm{Cl}$ versus $(\mathrm{Ca}+\mathrm{Mg})-\left(\mathrm{SO}_{4}-\mathrm{HCO}_{3}\right)$ plot for groundwater of the Ga West Municipal Area

$\mathrm{Cl}^{-}$concentrations increased substantially with well depths. The boreholes with deeper depths recorded very high values as compared to the hand dug wells which have shallow depths. The $\mathrm{Na}^{+}$values vary from 26.1 to $557 \mathrm{mg} / \mathrm{L}$ with a mean of $197 \mathrm{mg} / \mathrm{L}$. $\mathrm{Cl}^{-}$concentrations also vary from 25 to $1,348 \mathrm{mg} / \mathrm{L}$ with a mean of $289 \mathrm{mg} / \mathrm{L}$. The correlations between the major ions were done using the Spearman's correlation analysis and the results are shown in Table 2. High positive correlation $(r=0.72)$ was found between $\mathrm{Na}^{+}$and $\mathrm{Cl}^{-}$and very high positive correlation ( $r=0.82$ and 0.94 ) between total dissolved solids (TDS) and both $\mathrm{Na}^{+}$and $\mathrm{Cl}^{-}$, respectively. The correlations between TDS and $\mathrm{Mg}^{2+}(r=0.69)$ and $\mathrm{SO}_{4}{ }^{2-}(r=0.69)$ are low but also significant $(r=0.3)$ at $1 \%$ level. On the other hand, correlations between other ions and TDS and among themselves though positive $(r<6.0$ at $1 \%$ level) are significantly low suggesting that TDS is derived mainly from $\mathrm{Na}^{+}$to $\mathrm{Cl}^{-}$. Since the correlation coefficient between
$\mathrm{Na}^{+}$and $\mathrm{Cl}^{-}$is positively high, it can also be deduced that for most of the groundwater samples $\mathrm{Na}^{+}$and $\mathrm{Cl}^{-}$originate from a common source.

The maximum and minimum values for potassium both occur in shallow wells. The maximum value of $121 \mathrm{mg} / \mathrm{L}$ occurs at Amasaman, whereas the minimum also occurs at Amasaman. The mean concentration is $16.7 \mathrm{mg} / \mathrm{L}$. Bicarbonate concentration varies from 5 to $570 \mathrm{mg} / \mathrm{L}$. The mean value is $194 \mathrm{mg} / \mathrm{L}$. The highest value of $570 \mathrm{mg} / \mathrm{L}$ occurs in a hand dug well at Afiaman and the lowest in a borehole at Asofaa. The dominance of $\mathrm{HCO}_{3}{ }^{-}$in the shallow water samples could be attributed to the atmospheric gases present in the soil or in the unsaturated zone lying between the surface of the land and the water table (Hem 1985), but it may also reflect the water-rock interaction in the study area. Nitrate in groundwaters of the study area ranges from 0.01 to $49 \mathrm{mg} / \mathrm{L}$. The mean is $30 \mathrm{mg} / \mathrm{L}$. The highest values as expected were observed in hand dug wells. This observation compares favourably with earlier work by Fianko et al. (2008) in groundwater of the Densu River Basin, where agriculture, spreading of animal manure, sewage sludge and effluent were deduced as the probable causes of increased levels of nitrate in the groundwaters. If agricultural practices are one of the significant factors deteriorating groundwater quality in this study, then a positive relationship between nitrate and potassium is expected. However, the regression line of $\mathrm{NO}_{3}{ }^{-}$and $\mathrm{K}^{+}$(Fig. 5) is not linear, indicating that agricultural practices are not significant in the study area. A few hand dug wells were observed to be very close to pit latrines and refuse dumps, some within $10 \mathrm{~m}$ of these sites. These hand dug wells showed slight increase in nitrate levels as compared to the boreholes.
Fig. 8 Schoeller diagram of the median concentrations of anions and cations of shallow and deep groundwaters in the Ga West Municipal Area

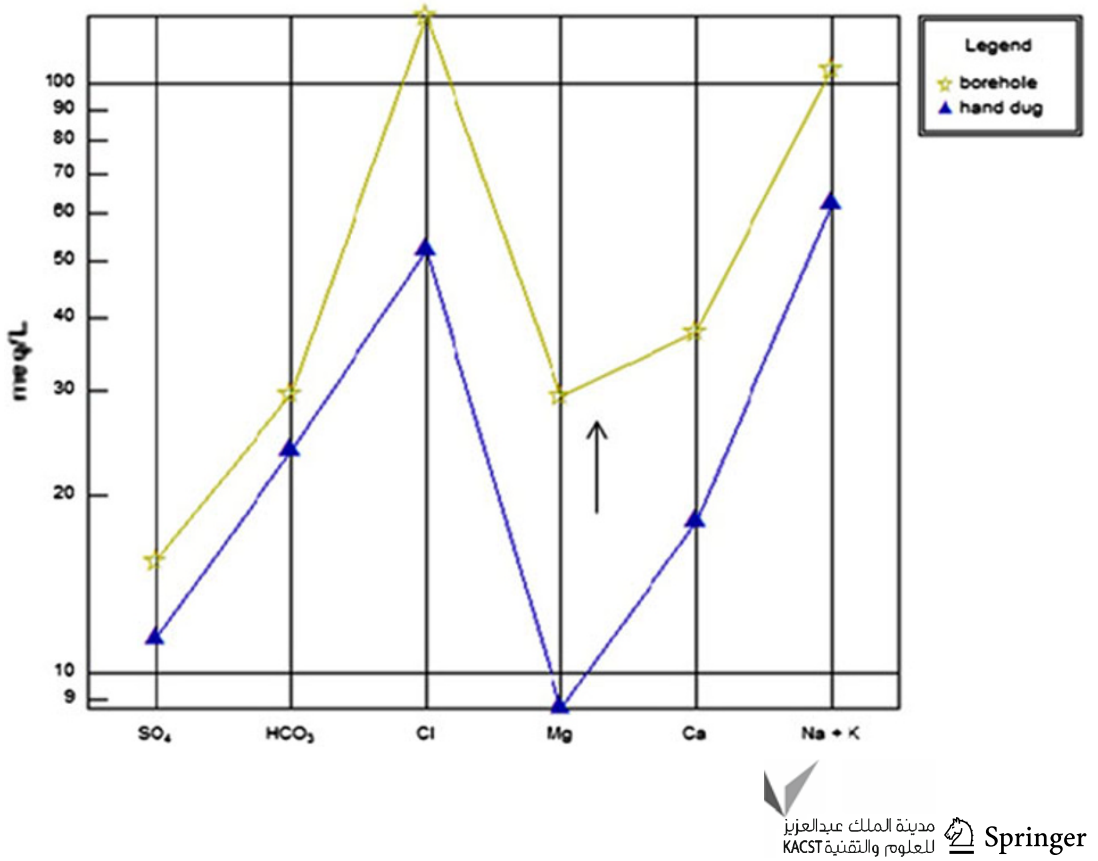


Table 3 Isotopic composition and geographical coordinates of samples in the Ga West Municipal Area

\begin{tabular}{|c|c|c|c|c|c|c|c|}
\hline Sample no. & Sample location & Well ID & Lat. $\left({ }^{\circ} \mathrm{W}\right)$ & Long. $\left({ }^{\circ} \mathrm{N}\right)$ & $\delta^{18} \mathrm{O}(\%)$ & $\delta^{2} \mathrm{H}(\%)$ & d-Excess \\
\hline 1 & Katapor & BH-1 & 0.155 & 5.433 & -3.39 & -13.09 & 14.1 \\
\hline 2 & Katapor & BH-2 & 0.156 & 5.433 & -3.11 & -10.72 & 14.2 \\
\hline 3 & Katapor & BH-3 & 0.155 & 5.433 & -3.20 & -14.05 & 11.6 \\
\hline 4 & Katapor & BH-4 & 0.161 & 5.432 & -2.34 & -9.53 & 9.2 \\
\hline 5 & Mayera & SW-1 & 0.162 & 5.432 & -2.56 & -5.75 & 14.8 \\
\hline 6 & Mayera & BH-5 & 0.163 & 5.433 & -2.07 & -6.45 & 10.1 \\
\hline 7 & Mayera & BH-6 & 0.164 & 5.433 & -1.89 & -7.09 & 8.0 \\
\hline 8 & Mayera & SW-2 & 0.164 & 5.433 & -1.22 & -2.94 & 6.9 \\
\hline 9 & Abese & HD-1 & 0.162 & 5.426 & -3.20 & -10.91 & 14.7 \\
\hline 10 & Afiaman & HD-2 & 0.171 & 5.423 & -1.84 & -4.43 & 10.3 \\
\hline 11 & Afiaman & HD-3 & 0.171 & 5.423 & -2.43 & -5.87 & 13.5 \\
\hline 12 & Afiaman & BH-7 & 0.172 & 5.423 & -2.43 & -8.94 & 10.5 \\
\hline 13 & Afiaman & HD-4 & 0.173 & 5.424 & -2.30 & -8.45 & 9.9 \\
\hline 14 & Shikpontele & HD-5 & 0.182 & 5.431 & -2.06 & -7.54 & 8.9 \\
\hline 16 & Sarpeiman & HD-7 & 0.184 & 5.434 & -2.48 & -8.68 & 11.1 \\
\hline 17 & Agbon No.1 & HD-8 & 0.184 & 5.435 & -2.44 & -11.64 & 7.9 \\
\hline 18 & Agbon No.1 & BH-8 & 0.184 & 5.436 & -2.64 & -11.99 & 9.1 \\
\hline 19 & Sarpeiman & HD-9 & 0.184 & 5.433 & -2.14 & -6.63 & 10.5 \\
\hline 20 & Amasaman & HD-10 & 0.182 & 5.424 & -2.50 & -10.02 & 10.0 \\
\hline 21 & Amasaman & HD-11 & 0.181 & 5.423 & -2.00 & -10.62 & 5.4 \\
\hline 22 & Amasaman & HD-12 & 0.175 & 5.421 & -2.15 & -7.96 & 9.2 \\
\hline 23 & Fise & HD-13 & 0.176 & 5.415 & -2.04 & -9.84 & 6.5 \\
\hline 24 & Fise & HD-14 & 0.176 & 5.414 & -1.81 & -7.18 & 7.3 \\
\hline 25 & Amanfro & HD-15 & 0.174 & 5.406 & -2.53 & -6.63 & 13.6 \\
\hline 26 & Amanfro & BH-9 & 0.174 & 5.410 & -2.34 & -5.26 & 13.5 \\
\hline 27 & Amanfro & HD-16 & 0.174 & 5.410 & -1.91 & -4.84 & 10.5 \\
\hline 28 & Amanfro & SW-3 & 0.174 & 5.410 & -1.71 & -5.11 & 8.6 \\
\hline 29 & Asofaa & BH-10 & 0.162 & 5.393 & -2.20 & -7.37 & 10.2 \\
\hline 30 & Ofankor & HD-17 & 0.162 & 5.394 & -2.84 & -14.65 & 8.0 \\
\hline
\end{tabular}

$B H$ borehole, $H D$ hand dug well, $S W$ surface water

The sulphate concentration in the groundwaters is generally low varying from 0 to $257.8 \mathrm{mg} / \mathrm{L}$. The mean is $60 \mathrm{mg} / \mathrm{L}$. The sulphate analyses show variations in both boreholes and hand dug wells.

\section{Hydrochemical facies}

The hydrochemical compositions of the water samples were plotted on a Piper diagram (Fig. 6) to understand the processes affecting the groundwater of the study area (Piper 1953). Two main hydrochemical water types have been identified. These are sodium chloride and mixed water types.

The dominant water type is sodium chloride. In the cation plot field most of the samples plot towards the $\mathrm{Na}+\mathrm{K}$ corner and in the anion field the samples plot towards the $\mathrm{Cl}$ corner. This water type is characterized by high TDS and conductivity. Groundwater of this composition is most likely derived from contact with saline water.
Coincidentally, this water type is mostly observed in the deeper groundwaters, especially towards the south-western parts of the study area. Mineral weathering processes may also play a role in the evolution of this water type. The mixing process of freshwater and saline water is observed in the shift from $\mathrm{Ca}-\mathrm{HCO}_{3}$ water type to $\mathrm{Ca}-\mathrm{Cl}$ water type. The Piper plot also shows a shift from $\mathrm{Ca}$ to Na-rich water type. This shift from $\mathrm{Ca}-\mathrm{Cl}$ water type to $\mathrm{Na}-\mathrm{Cl}$ water type suggests that the chemistry of the groundwater was controlled by a mixing process and a cation exchange process (Vengosh et al. 1991; Appelo and Postma 2005). The change between $\mathrm{Ca}-\mathrm{Cl}$ water type and $\mathrm{Na}-\mathrm{Cl}$ water type showed that the cation exchange process was controlled by a salinization process of the aquifer. A close examination of the plot of $\mathrm{Na}-\mathrm{Cl}$ versus $\left(\mathrm{Ca}+\mathrm{Mg}-\mathrm{SO}_{4}+\mathrm{HCO}_{3}\right)$ (Fig. 7) showed an inverse relationship, which indicates that $\mathrm{Ca}$ and $\mathrm{Mg}$ concentrations in groundwater are derived from aquifer materials. 
Fig. 9 Relationship between hydrogen and oxygen isotopes for rainwater, borehole and hand dug wells in the Ga West Municipal Area

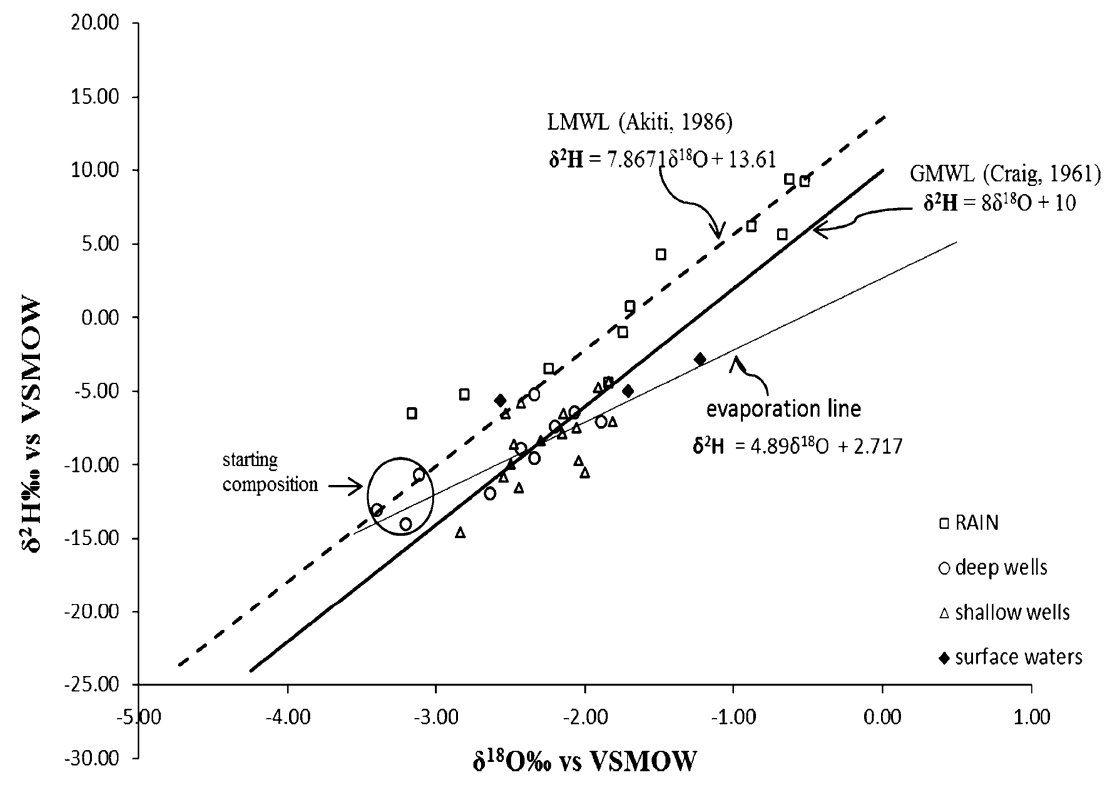

The Schoeller diagram

The Schoeller (1955) diagram allows the major ions of many samples to be represented on a single graph, in which samples with similar patterns can be easily discriminated. The diagram shows the total concentration of major ions in semi log-scale. If a straight line joining the points for two elements $\mathrm{A}$ and $\mathrm{B}$ in one type of water is parallel to another straight line joining the parts for the same elements $A^{1}$ and $\mathrm{B}^{1}$ in another type of water, the ratio of these elements is the same in either case, that is, $A / B=A^{1} / B^{1}$. If the waters have different concentrations, they will appear on the graph one above the other, thus indicating relative movement of the groundwater between the points of origin of these analyses; the flow being from a lower concentration to a higher concentration (Charron 1969).

The groundwater samples are grouped into two and the median concentrations of their anions $\left(\mathrm{SO}_{4}{ }^{2-}, \mathrm{HCO}_{3}{ }^{-}\right.$, $\left.\mathrm{Cl}^{-}\right)$and cations $\left(\mathrm{Mg}^{2+}, \mathrm{Ca}^{2+}, \mathrm{Na}^{+}, \mathrm{K}^{+}\right)$plotted on the Schoeller diagram (Fig. 8). Group 1 represents hand dug wells which are the shallow groundwaters with depths not more than $30 \mathrm{~m}$ and Group 2 represents boreholes which are the deep groundwaters.

Examination of the Schoeller diagram shows similar slope of lines connecting solute concentrations. This is an indication of groundwater from a similar source. The plot shows a gradual increase in all the anion and cation concentrations towards the deep groundwaters. This pattern is understandable because the shallow groundwater is close to the earth's surface and has not had time to dissolve more soluble solutes. Early studies by Chebotarev (1955); Schoeller (1955) suggest that groundwater composition changes progressively along a flow path towards the composition of saline water (increase in TDS and concentration of dissolved salts, etc.).

A close look at the Schoeller plot also shows that the $\mathrm{Mg}^{2+}$ value of group 1 is very low. This may be due to the absence of ferromagnesian minerals in the rocks of the shallow aquifers. However, this value is seen to increase substantially in the deep groundwaters of group 2, indicating that the aquifer could be making contact with a dolomitic mineral which may be dissolving magnesium into the groundwater.

Isotopic composition of rainfall

The isotope composition of rainfall, groundwater and surface water are listed in Table 3. The rainfall data have $\delta^{18} \mathrm{O}$ ranging from -3.16 to $-0.52 \%$ and $\delta^{2} \mathrm{H}$ ranging from -6.52 to $9.37 \%$. The average values of $\delta^{18} \mathrm{O}$ and $\delta^{2} \mathrm{H}$ in rainwater are -1.61 and $1.33 \%$, respectively. The equation for the best-fit regression line is

$\delta^{2} \mathrm{H}=6.2 \delta^{18} \mathrm{O}+11\left(R^{2}=0.89\right) \quad n=11$

The slope of the regression line for this study is smaller as compared to that developed by Gibrilla et al. (2010) for the Northern Densu River Basin $\left(\delta^{2} \mathrm{H}=7.46 \delta^{18} \mathrm{O}+\right.$ 12.16). The Northern Densu River Basin is located in a region which lies in the wet semi equatorial climatic zone. The Ga West Municipal Area, however, falls within the Southern Densu River Basin where the climate is drier with lower humidity conditions. The difference in the slope thus indicates different moisture sources for the rainfall in the two areas.

The rainwater samples are observed to plot close to the local meteoric water line (Fig. 9) [LMWL, $\delta^{2} \mathrm{H}=$ 
$7.86 \delta^{18} \mathrm{O}+13.61, n=8$ ] developed by Akiti (1986) for southern Ghana. This shows that the LMWL is what operates in the study area. The samples are however observed to spread out along the LMWL. This variability in the isotopic signatures is due to the various types of rainfall events in the study area. The municipal area is located in a semi-arid region and is characterized by a considerable amount of evaporation; therefore, evaporation during rainfall is possible. When rain is falling through a dry air column, some will evaporate. Large storm events would be likely to produce highly depleted rainfall signatures and small events would be expected to be more evaporative, particularly in this environment. Friedman et al. (1962) first showed that evaporation during rainfall would shift the water away from the Global Meteoric Water Line (GMWL) developed by Craig (1961) and expressed by the equation:

$\delta^{2} \mathrm{H}=8 \delta^{18} \mathrm{O}+10$

This relation was developed as an average of many local meteoric water lines that differ from the GMWL as a result of climatic and geographic factors. Comparing the rainwater samples with the GMWL, the rainwater samples plot on the LMWL, which indicate the occurrence of evaporation during rainfall. The LMWL is parallel to, but slightly offset above the GMWL as shown in Fig. 9.

\section{Isotope composition of groundwater}

The distribution of $\delta^{18} \mathrm{O}$ of both shallow and deep groundwater ranges from -3.39 to $-1.81 \%$, and $\delta^{2} \mathrm{H}$ from -14.65 to $-4.43 \%$. The mean values of $\delta^{18} \mathrm{O}$ and $\delta^{2} \mathrm{H}$ are -2.37 and $-8.86 \%$, respectively. A plot of $\delta^{2} \mathrm{H}$ against $\delta^{18} \mathrm{O}$ of the analysed samples is shown in Fig. 9. The groundwater samples plot below the LMWL and along the evaporation line indicating that some of the groundwaters might have undergone evaporation on the land surface or in the unsaturated zone before recharge.

In semi-arid regions, the isotopic composition of groundwater can be considerably modified from that of local rainfall due to the strong isotopic enrichment in water during evaporation. Groundwaters that have undergone evaporation display systematic enrichment in stable isotopes, resulting in divergence from the LMWL along evaporation lines that have slopes of usually 4-6 (Gibson et al. 1993). Figure 9 reveals this trend in the groundwater samples. They are characterized by enrichment in isotopes.

Three deep groundwater samples plot close to the intersection of the evaporation line and the LMWL. Groundwaters that plot at the intercept of the evaporation line and the LMWL often provide useful approximation of the original isotopic composition of groundwater before evaporation. The intercept point is $-3.5 \%$ for $\delta^{18} \mathrm{O}$ and -

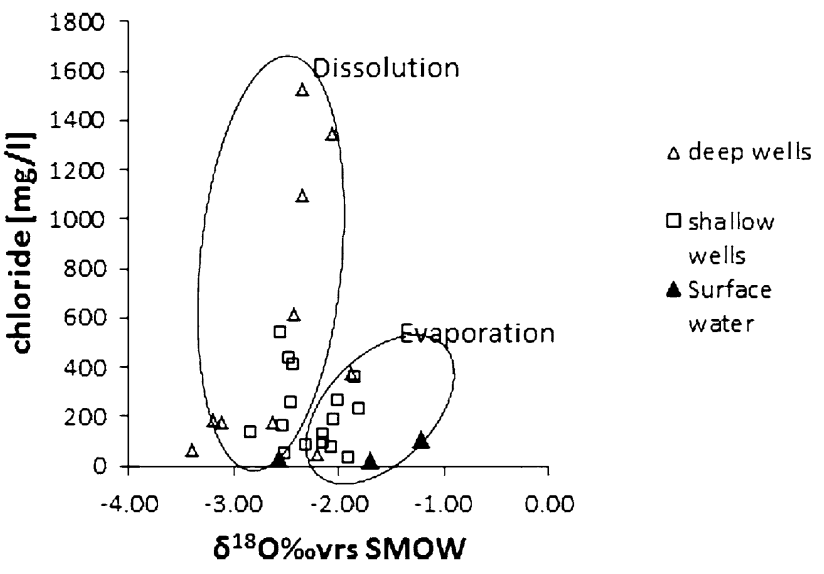

Fig. 10 Plot showing the relationship between chloride $(\mathrm{Cl})$ concentration and isotopic composition of oxygen $\left(\delta^{18} \mathrm{O}\right)$ for groundwater samples of the Ga West Municipal Area

$14.0 \%$ for $\delta^{2} \mathrm{H}$, respectively, and shows that the three deep groundwater samples are much more depleted than those of the average rainfall values for the area $\left(\delta^{18} \mathrm{O}=-\right.$ $1.61 \%$ and $\delta^{2} \mathrm{H}=1.33 \%$ ). Incidentally, all three samples were drawn within the Katapor community at the extreme northeast of the study area (Fig. 3). This area falls within the Togo Formation and at the foot of the Akwapim-Togo Range of Mountains. This area can safely be considered as a recharge zone for the study area.

Majority of the groundwater samples plot in a relatively narrow cluster and have a fairly consistent signature close to the intersection of the GMWL and the evaporation line.

Two of the surface water samples plot on the upper righthand side of the evaporation line, indicating that these surface waters suffer evaporation. However, one plots on the LMWL. This river was sampled very close (about $1 \mathrm{~km}$ ) to its source in a forested area at the foothills of the TogoAkwapim Range. Due to the forest tree cover and the short travel time of the river, the water might not have experienced much evaporation accounting for its position on the LMWL.

A plot of chloride versus $\delta^{18} \mathrm{O}$ is illustrated in Fig. 10 to understand the mechanism of salinization for the groundwater of the study area. In the diagram, two water types are observed; the first type is waters in which dissolution of soluble salts leads to salinization. In this water type, increase in chloride concentration does not correspond with enrichment of $\delta^{18} \mathrm{O}$. Most of the boreholes and about half of the hand dug wells belong to this group.

The second water types are those affected by evaporation. Increase in chloride concentration in this water type corresponds with a gradual increase in $\delta^{18} \mathrm{O}$ composition. The other half of the hand dug wells belongs to this group. Dissolution of soluble salts could be a major contributory factor for groundwater salinity especially in the boreholes, whereas evaporation could also account for salinity in the shallow wells in the study area. 


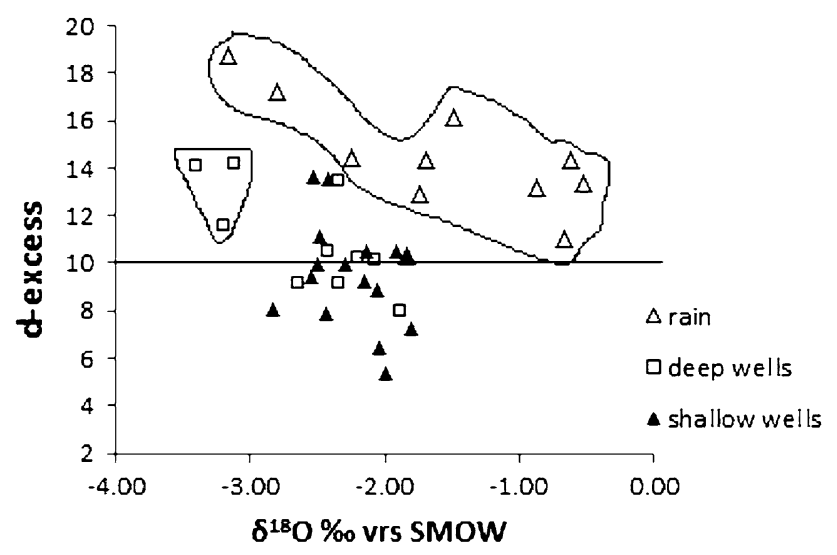

Fig. 11 Comparison of deuterium excess with $\delta^{18} \mathrm{O}$ in rainwater, boreholes and hand dug wells at the Ga West Municipal Area

\section{Deuterium excess}

The deuterium excess (or d-excess), defined as d (\%o) $=\delta^{2} \mathrm{H}-$ $8 \delta^{18} \mathrm{O}$ (Dansgaard 1964), has shown to be a useful parameter to trace the effect of evaporation in modifying the isotopic character of rainwater prior to groundwater recharge. In the Global Meteoric Water line d-excess has a value of $\sim 10$ representing evaporation at $\sim 85 \%$ relative humidity. However, the 'd-excess' value in the regional precipitation can be $>10$ if the evaporation in the source region takes place under lower humidity (Gat and Carmi 1970). Alternatively, significant re-evaporation of local surface waters under low humidity creates vapour mass with high d-excess. If such a vapour mixes with atmospheric reservoir and re-condenses, the resultant precipitation will have high d-excess (Ingraham and Matthews 1988; Clark and Fritz 1997).

It is noted from Fig. 11 that for both shallow and deep groundwater samples, the d-excess values are less than ten in most parts of the study area except in some small packets, especially in wells located in the northeast of the study area. The d-excess values in rainfall are observed to be above ten with an average of 14.2. The low values of d-excess in the groundwaters at most parts of the study area suggest that there is significant evaporation of rainwater, leaving the residual groundwater with lower values of d-excess. This is also supported by the regression line slope values for groundwaters being lower than that in the rainfall.

The groundwaters with high d-excess are located near the foothills of the Akwapim-Togo Ranges which are regarded as the recharge areas, thus the d-excess shift in these areas towards that of the rainfall may suggest a modern recharge to the groundwater system in the area.

\section{Conclusions}

Groundwater data from the Ga West Municipal Area of Ghana were analysed using the ratios of the major ions,
Piper diagram, Schoeller diagram and stable isotopes to determine the geochemical processes and recharge pattern in the area. The groundwaters would generally be classified as slightly acidic to neutral. High nitrate concentrations were noted in some hand dug wells. However, significant agricultural practices were not observed near these hand dug wells and a nonlinear relationship between $\mathrm{NO}_{3}{ }^{-}$and $\mathrm{K}^{+}$also suggests that agricultural practices do not contribute to the high nitrate levels. The nitrates might thus be attributed to proximity of the hand dug wells to pit latrines and refuse dumps.

Hydrochemical facies identified two main water types: $\mathrm{Na}-\mathrm{Cl}$ and mixed water types. Schoeller diagram gave an indication that groundwater in the study area is recharged from a similar source. The Schoeller diagram also showed that there is a gradual increase in all the ion concentrations with depth of boreholes.

The isotopic compositions of oxygen and hydrogen for rainwater and groundwater samples suggest that the main source of groundwater recharge is by direct rainfall infiltration. The isotopes also suggest that the shallow wells in particular are recharged by evaporated rainwater either on the ground surface or in the unsaturated zone. The d-excess values in both rainfall and groundwater have average values of 14.2 and 10.2, respectively. This shows that the d-excess in groundwaters of the study area may be inherited from the rainfall. The plot of chloride concentration versus oxygen isotope composition showed two trends; one of increasing concentration of chloride with enrichment of oxygen-18 for hand dug wells and another of constant oxygen-18 composition with increasing concentration of chloride for the boreholes. This observation confirms the suggestion that the shallow groundwater is recharged from evaporated raindrops and concentration of chloride at greater depths leads to salinization in the deep wells.

Acknowledgments The authors wish to thank the staff of the Nuclear Chemistry and Environmental Research Centre, NNRI, GAEC. We are also grateful to Prof Samuel B. Dampare and $\mathrm{Mr}$ Edward P.K. Bam for reviewing this work and making priceless suggestions. Finally, we thank Mr. Eric Obeng Agyekum for his support during the sampling.

Open Access This article is distributed under the terms of the Creative Commons Attribution License which permits any use, distribution, and reproduction in any medium, provided the original author(s) and the source are credited.

\section{References}

Ahmed SM, Blay PK, Casto SB, Coakley GJ (1977) Geology of (1/4) ${ }^{\circ}$ field sheets nos. 33 Winneba NE 59, 61, and 62 Accra SW, NW and NE. Ghana Geological Surv Bulletin No. 32 pp 1-18

Akiti TT (1986) Environmental isotope study of groundwater in crystalline rocks of the accra plains, Ghana, 4th working 
meeting, isotopes in nature. In: Proceedings of an advisory group meeting Leipzig, pp 107-121

Appelo CAJ, Postma D (2005) Geochemistry, groundwater and pollution, 2nd edn. A.A Balkema, Rotterdam

Charron JE (1969) Hydrochemical interpretation of groundwater movement in the river valley, manitoba, department of energy, mines and resources, inland waters branch, Vol 2 The Queens Printer, Ottawa, pp 1-9

Chebotarev II (1955) Metamorphism of natural waters in the crust of weathering. Geochimica et Cosmochimica Acta 8:22-48 137-170, 198-212

Clark ID, Fritz P (1997) Environmental isotopes in hydrogeology. CRC Press, Boca Raton

Craig H (1961) Isotopic variation in meteoric water. Science 133:1702-1703

Dansgaard W (1964) Stable isotopes in precipitation. Tellus 16:436468

Fianko JR, Osae S, Adomako D, Achel DG (2008) Relationship between land use and groundwater quality in six districts in the eastern region of Ghana. Environ Monit Assess 153:139-146

Fianko JR, Adomako D, Osae S, Ganyaglo S, Kortatsi BK, Tay CK, Glover ET (2010) The hydrochemistry of groundwater in the Densu river basin, Ghana. Environ Monit Assess 167:663-674

Friedman O, Machta L, Soller R (1962) Water vapour exchange between a water droplet and its environment. J Geophys Res 67:2761-2766

Ganyaglo SY, Banoeng-Yakubo B, Osae S, Dampare SB, Fianko JR, Bhuiyan MAH (2010) Hydrochemical and isotopic characterisation of groundwaters in the eastern region of Ghana. J. Water Resour Protection 2:199-208

Gat JR, Carmi I (1970) Evolution of the isotopic composition of atmospheric waters in the mediterranean sea area. J Geophys Res 75:3039-3048

Ghana Statistical Service (2002) 2000 Population and Housing Census, Summary Report of Final Results

Gibrilla A, Osae S, Akiti TT, Adomako D, Ganyaglo SY, Bam EPK, Hadisu A (2010) Origin of dissolve ions in groundwaters in the northern Densu river basin of Ghana using stable isotopes of ${ }^{18} \mathrm{O}$ and ${ }^{2} \mathrm{H}$. J. Water Resour Protection 2:1010-1019

Gibson JJ, Edwards TWD, Bursey GG (1993) Estimating evaporation using stable isotopes: quantitative results and sensitivity analysis for two catchments in northern Canada. Nord Hydrol 24:79-94

Gyau-Boakye P, Dapaah-Siakwan S (2000) Groundwater as source of rural water supply in Ghana. J appl sci tech (JAST) 5:77-86

Hem DJ (1985) Study and interpretation of the chemical characteristics of natural water. 3rd edn. U.S. Geological Survey Alexandria, pp 89-90, 100-102
Ingraham NL, Matthews RA (1988) Fog drip as a source of groundwater recharge in northern Kenya. Water Resour Res 24:1406-1410

Kesse GO (1985) The mineral and rock resources of Ghana. Balkema, Rotterdam, pp 13-26, 40-67

Kofie R, Attua E, Nabila J (2008) Poverty and socio-economic consequences of buruli ulcer (Mycobacterium ulcerans) in the Ga West District of Ghana. Norwegian J Geography 62(12): 210-221

Kortatsi BK (1994) Groundwater utilization in Ghana. Paper presented at the future groundwater resources at risk (Proceedings of the Helsinki conference, June 1994). IAHS Publ no 222:1994

Nkansah MA, Owusu Boadi N, Badu M (2010) Assessment of the quality of water from hand dug wells in Ghana. Environmental Health Insights 4:7-12

Owusu EA, Gasu AQ (2002) Application of geo-information and techniques in identifying and mapping land degradation problems within Amasaman-Pokuase (Northeast of Accra) and its surrounding areas, AAPG search and discovery article \#0007 AAPG annual meeting. Houston, Texas

Pelig-Ba KB (1989) On an Investigation of the water quality problem on borehole AP216 at Oyibi. Unpubl Report Water Resour Res Inst, Accra, p 20

Piper AM (1953) A graphic procedure in the geochemical interpretation of water analysis. US Geological Survey, Washington DC

Saunders RS (1969) Early palaeozoic orogeny in Ghana: foreland stratigraphy and structure. Department Geological Sciences, Brown University, Providence, Rhode Island 02912

Schoeller H (1955) Geochimie des eauxsouterraines application aux eaux de gisements de petrole; Revue Inst. Petrole et Ann des combustibles liquids 10(181-213):219-246

Vengosh A, Starinsky A, Melloul A, Fink M, Erlich S (1991) Salinization of the coastal aquifer water by $\mathrm{Ca}-\mathrm{Chloride}$ solutions at the interface zone, along the coastal plain of Israel. Hydrological Service of Israel Report 20/1991

Water Resources Research Institute, WRRI (2003) Groundwater assessment: an element of integral water resources managementthe case of the Densu river basin

Wright JB, Hastings DA, Jones WB, Williams HR (1985) Geology and Mineral Resources of West Africa. George Allen \& Unwin (Publishers) Ltd, London, UK

Yidana SM, Banoeng-Yakubo B, Akabzaa T, Asiedu D (2011) Characterization of the groundwater flow regime and hydrochemistry of groundwater from the Buem formation, Eastern Ghana. Hydrol Proc 25(14):2288-2301 